\begin{tabular}{lcr}
\hline & ANNALES & \\
& & \\
UNIVERSITATIS MARIAE CURIE-SKLODOWSKA & \\
LOL. II & SECTIO M & 2017 \\
\hline
\end{tabular}

Agnieszka Wicha

Cardinal Stefan Wyszyński University in Warsaw

\title{
The Scientific Review of Personal Finance. Competences - Tools - Institutions - Products - Decisions by Prof. Róża Milic-Czerniak
}

The bibliographical data about the scientific paper:

- the author: Róża Milic-Czerniak, prof.

- the title: Personal Finance. Competences - Tools - Institutions - Products Decisions

- the place of edition: Warsaw

- the year of edition: 2016

- the publishing house: Difin Publishing House

- the number of pages: 388

The information about the author of the paper:

Róża Milic-Czerniak is a member of the Banking Commission of Ethics by Polish Banking Association and a professor at UTH University in Warsaw. She has extensive experience in a banking sector (more than 18 years of experience in the field of banking).

She worked on managerical positions in one of the biggest banks in Poland, where she was responsible for developing capital management, methodology of a product and a client profitability concerning costs of risk, capital and costs allocation. She is an author of several books and research papers. She was in the fellowship of Alexander von Humboldt-Stiftung. Róża Milic-Czerniak is one of the co-authors of the manual BANKING for practitioners of European Certificate of a Banker (EFCB 3E). 
1. The presentation of the key theses and the structure of the scientific paper

The scientific paper which is reviewed is a collective paper scientifically edited by prof. Róża Milic-Czerniak. The paper is interdisciplinary and is addressed to a natural person in a household. It is stated expressis verbis in the introduction that the strategic goal of the scientific book was to provide a household with knowledge on the management of finance and to expand the awareness of decision-making processes.

The publication is divided into 12 chapters. The first chapter introduces the concept of personal finance and the finance at a household's disposal. The presentation of the key concepts was made via understanding the definition of finance as a scientific notion.

The second chapter is the analysis of a household as a member of a financial market. In the second chapter the notions known from the economic surrounding of a household are presented. In the third chapter there is a description of the tools which can be used by a household while managing the finance. The fourth chapter is the presentation of special computer applications (Personal Finance Management). The tool which is described is quite a modern one in the Republic of Poland. Personal Management Tools appeared on the market some years ago and in the United States of America had already been widely used.

The fifth chapter is written from a different perspective because it focuses on motivations and patterns of the members of a household in the scope of savings and investment. The continuation of this notion is in the sixth chapter which introduces the concept of behavioral finance.

The chapters 7-10 present specialised concepts concerning liabilities, social insurance of the employers, market insurance and taxes. Chapter 11 forms a complex presentation of the notion of client protection on the market of financial services. The last chapter is a theoretical part where basic concepts are presented. There is a presentation of the notions taken from mathematics (e.g. percent) and formulas which explain the way of counting of several actions present in a banking sector - from the amount of a loan, an installment loan in a foreign currency, etc.

Twelve chapters of a book are preceded with an introduction which presents the intentions of the authors of scientific publications and a short characteristics of the chapters. 


\section{Critical analysis}

The publication is dedicated to natural people and the researchers of a financial sector as well. Such an interdisciplinary approach where there is the analysis of the financial issues which concern a natural party is very original. Making the research by many domestic and international institutions and organisations indicates a continuing strive to get knowledge and become familiarised with concepts and notions concerning the world of finance.

Nevertheless, the deficit of knowledge is easily visible as it may lead to wrong financial decisions, undue disposal of goods, bad management, easily sliding into poverty. One gets easily affected by frustration because of lack of knowledge concerning a banking sector. It was stated that there is a vast concept of non-satisfactory financial resources.

Standard \& Poor's made the research on economic knowledge of the inhabitants of 140 divergent states in the whole world (150 000 adult people questioned). In the research the attempt to check in a practical way the application of basic economic notions was made. It turned out that as many as $42 \%$ of adult Poles do not distinguish basis economic concepts (e.g. inflation, a compound interest). On a global scale, the result is even worse - as few as $33 \%$ do not understand simple economic concepts ${ }^{1}$.

In the research made by the Institute of Freedom and Reiffeisen Polbank it was revealed that $92 \%$ of Poles could not distinguish the notion of a percent from a percentage point, $25 \%$ of those who participated in the research could not state what value added tax was ${ }^{2}$.

The data revealed for the research display the vast necessity for further education, mainly on an elementary level.

Such a publication is innovative as it is one of the means to expand the awareness of the economic aspects of Poles. One needs to note the development of a financial sector, its expansion of products and financial services available on the market, in particular connected with investment and saving. The increase in the number and the complexity of products is indispensable while making decisions which imply the growth of the level of the knowledge of a natural party.

Still, there is a question if, and how, the knowledge presented by scholars can be used by members of a household. The application of knowledge from the

1 The website of the portal Finance, http://www.finanse.egospodarka.pl, Wiedza ekonomiczna Polaków na niskim poziomie, access 1 IX 2017.

2 The website of the portal Instytut Wolności, http://www.instytutwolnosci.pl, Stan wiedzy ekonomicznej Polaków, access 1 IX 2017. 
twelfth chapter cannot be possible anyhow as it is extremely difficult for a natural party to make use of the concepts as a natural party is - as a name suggests - no professional in the field.

The presentation of complicated formulas and advanced patterns does not seem to be a due concept for members of a household to become familiarised with the way to count given amounts of particular financial products. Nonetheless, the presentation of the tools of finance management in the third chapter might be easily applied. There might be the case that in practice not many of natural people will prepare specialised tables as presented in the book. Still, the analysis of the expenditures and income (monthly or yearly) is a tool which is widely used. Therefore, the third chapter may be a good key to make the awareness of a natural person increased.

The first two chapters form a significant introduction for the topic and the formation of a structure of a scientific paper is made at the beginning. From the perspective of the readers, it is a comprehensive part enhancing reflection on finance, the role of finance, the presence of numerous financial operations.

A particular attention is paid to the protection of a client. The institutions which take care about the protection of a client are presented and enumerated. Such a set is valuable for clients who have the list of the institutions in one place. Such institutions may be helpful and provide with a piece of knowledge in the case of a dispute between a client and a financial institution.

There is a presentation of legal bases - from the Constitution of the Republic of Poland to the sources of law in the European Union and they are the most important in the scope of the protection of a client.

Because of territorial proximity, the first instance of a contact in case of the need for help is a local spokesperson. They help for free and work in municipal governments ${ }^{3}$. There is the search engine in the Office of Competition and Consumer Protection in the Republic of Poland useful to provide clients with the suitable information concerning the issue ${ }^{4}$.

3 The website of The Office of Competition and Consumer Protection in Poland, https://uokik. gov.pl, Rzecznicy, access 30 VIII 2017.

4 The website of The Office of Competition and Consumer Protection in Poland, https://uokik. gov.pl, Pomoc, access 30 VIII 2017. 